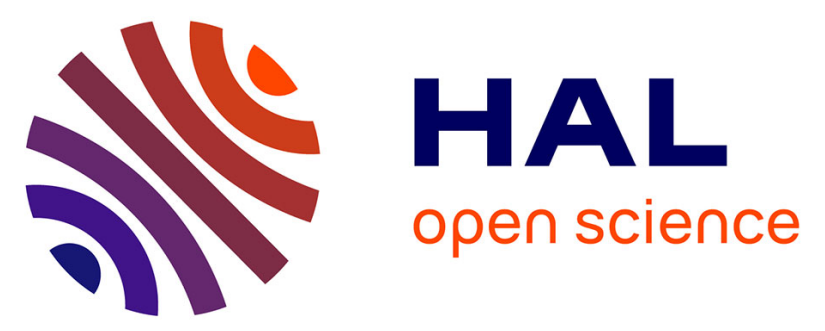

\title{
Adipose-derived stem cell adhesion on laminin-coated microcarriers improves commitment toward the cardiomyogenic lineage
}

\author{
Jean-Pierre Karam, Francesca Bonafé, Laurence Sindji, Claudio Muscari, \\ Claudia Montero-Menei
}

\section{To cite this version:}

Jean-Pierre Karam, Francesca Bonafé, Laurence Sindji, Claudio Muscari, Claudia Montero-Menei. Adipose-derived stem cell adhesion on laminin-coated microcarriers improves commitment toward the cardiomyogenic lineage. Journal of Biomedical Materials Research Part A, 2015, 103 (5), pp.1828-1839. 10.1002/jbm.a.35304 . hal-01392452

\section{HAL Id: hal-01392452 \\ https://hal.science/hal-01392452}

Submitted on 8 Oct 2021

HAL is a multi-disciplinary open access archive for the deposit and dissemination of scientific research documents, whether they are published or not. The documents may come from teaching and research institutions in France or abroad, or from public or private research centers.
L'archive ouverte pluridisciplinaire HAL, est destinée au dépôt et à la diffusion de documents scientifiques de niveau recherche, publiés ou non, émanant des établissements d'enseignement et de recherche français ou étrangers, des laboratoires publics ou privés. 


\title{
Adipose-derived stem cell adhesion on laminin-coated microcarriers improves commitment toward the cardiomyogenic lineage
}

\author{
Jean-Pierre Karam, ${ }^{1,2,3,4}$ Francesca Bonafè, ${ }^{3,4}$ Laurence Sindji, ${ }^{1,2}$ Claudio Muscari, ${ }^{3,4 *}$ \\ Claudia N. Montero-Menei ${ }^{1,2 *}$ \\ ${ }^{1}$ LUNAM Université, UMR S-1066 F-49933 Angers, France \\ ${ }^{2}$ NSERM U1066, MINT “Micro et nanomédecines biomimétiques," F-49933 Angers, France \\ ${ }^{3}$ INRC—National Institute for Cardiovascular Research, 40126 Bologna, Italy \\ ${ }^{4}$ Department of Biomedical and Neuromotor Sciences, University of Bologna, 40126 Bologna, Italy
}

\begin{abstract}
For tissue-engineering studies of the infarcted heart it is essential to identify a source of cells that may provide cardiomyocyte progenitors, which is easy to amplify, accessible in adults, and allowing autologous grafts. Preclinical studies have shown that human adipose-derived stem cells (ADSCs) can differentiate into cardiomyocyte-like cells and improve heart function in myocardial infarction. We have developed pharmacologically active microcarriers (PAMs) which are biodegradable and biocompatible polymeric microspheres conveying cells on their biomimetic surface, therefore providing an adequate three-dimensional (3D) microenvironment. Moreover, they can release a growth factor in a prolonged manner. In order to implement ADSCs and PAMs for cardiac tissue engineering we first defined the biomimetic surface by studying the influence of matrix molecules laminin (LM) and fibronectin (FN), in combination with growth factors present in the cardiogenic niche, to further enhance the in vitro cardiac differentiation of ADSCs. We
\end{abstract}

\section{INTRODUCTION}

Myocardial infarction (MI) constitutes the first cause of morbidity and mortality in developed countries. After MI, a necrotic and poorly vascularized zone appears, damaged cardiomyocytes are removed by macrophages and gradually replaced by scar tissue due to the limited intrinsic regenerative capacity of the heart. Current treatments present certain limitations, particularly for heart tissue repair, hence, in recent years, cell-based therapies have attracted considerable interest as an alternative way of achieving cardiac repair. Adipose derived-stem cells (ADSCs) possess a large differentiation potential and can be easily harvested from adipose tissue and amplified in culture. ${ }^{1-3}$ Under specific demonstrated that LM increased the expression of cardiac markers (Nkx2.5, GATA4, MEF2C) by ADSCs after 2 weeks in vitro. Interestingly, our results suggest that the $3 \mathrm{D}$ support provided by PAMs with a LM biomimetic surface (LM-PAMs) further enhanced the expression of cardiac markers and induced the expression of a more mature contractile protein, cardiac troponin I, compared with the 2D differentiating conditions after only 1 week in culture. The enrichment of the growth-factor cocktail with TGF- $\beta 1$ potentiated the cardiomyogenic differentiation. These results suggest that PAMs offering a LM biomimetic surface may be efficiently used for applications combining adult stem cells in tissue-engineering strategies of the ischemic heart. ( $) 2014$ Wiley Periodicals, Inc. J Biomed Mater Res Part A: 00A:000-000, 2014.

Key Words: adipose-derived stem cells, laminin, fibronectin, TGF- $\beta 1$, pharmacologically active microcarriers, 3D cardiomyogenic differentiation

*These authors contributed equally to this work.

Correspondence to: C. N. Montero-Menei; e-mail: claudia.montero-menei@univ-angers.fr

Contract grant sponsor: "Angers Loire Métropole" and “Inserm," France, National Institute for Cardiovascular Research (INRC), and Fondazione Dott. Carlo Fornasini, Italy 
The use of committed cells can be an alternative to overcome these concerns favoring their integration within the tissue. In this way, it appears necessary to improve the cardiomyogenic differentiation potential of ADSCs in order to optimize their future use in cell therapy studies.

It is known that the microenvironment plays an important role to determine the cardiac cell fate by means of mechani$\mathrm{cal}^{16,17}$ and molecular signals, such as cytokines and growth factors (GFs). ${ }^{18,19}$ Few in vitro studies performed with GFs have described cardiac commitment of a limited number of ADSCs especially in the presence of transforming growth factor beta 1 (TGF- $\beta 1)^{7}$ or of vascular endothelial growth factor (VEGF). ${ }^{6}$ Recent studies using bone marrow multipotent stromal cells (MSCs) and a GF cocktail have shown that a combination of GFs, that recapitulate the components of the endodermal secretome critical for cardiogenic induction of the embryonic mesoderm, ${ }^{20}$ allowed obtaining a more mature cardiac phenotype. ${ }^{21-23}$ The role of extracellular matrix (ECM) molecules that may further potentiate cardiomyogenic lineage induction in association with GF needs also to be taken into consideration. Indeed, early studies have shown a role of fibronectin (FN) and collagen in heart development ${ }^{24-26}$ and collagen and laminin (LM) for myocyte survival and proliferation. ${ }^{27}$ Among ECM molecules, LM and FN are the most extensively studied for their importance in cell adhesion, survival, and differentiation. ${ }^{28}$ They are expressed in the normal heart and increase after MI. ${ }^{29-32} \mathrm{FN}$ levels increase from $12 \mathrm{~h}$ onwards after MI in the human heart ${ }^{4}$ and LM is described to increase from 3 days post-MI. ${ }^{33}$

The combination of both GFs and ECM molecules supplied through the use of biomaterials to improve cell behavior within the infarcted area is an interesting strategy in regenerative medicine. Within this line, we have developed an innovative vector for tissue engineering named pharmacologically active microcarriers (PAMs). ${ }^{34}$ These PAMs are biodegradable and biocompatible poly-(lactic-co-glycolic) acid (PLGA) microspheres covered with ECM molecules, thus conveying cells on their biomimetic surface and providing a three-dimensional (3D) microenvironment for the transplanted cells which stimulates cell survival. ${ }^{35,36}$ Moreover, PAMs have a mean size of $60 \mu \mathrm{m}$ and can be easily implanted through a needle or catheter. They can also deliver a GF in a sustained and controlled manner for a prolonged period. $^{35,37,38}$ The combined parameters can stimulate the survival and/or differentiation of the transplanted cells toward a specific phenotype, therefore enhancing their engraftment but also affecting the host microenvironment allowing a better integration of the grafted cells and/or the stimulation of the injured tissue. ${ }^{35,38-40}$ However, it is important to first understand the potential of the PAMs not releasing GFs but providing a 3D biomimetic surface (biomimetic microcarriers), to stimulate cell survival and/or cardiac differentiation. Indeed, this type of PAMs are much easier to translate to the clinic and these properties have already been reported for PAMs not releasing GFs in a stroke model. ${ }^{36}$

In order to construct a tissue-like structure consisting of cardiac-committed ADSCs for heart transplantation, we first induced an early ADSC cardiomyogenic differentiation in vitro with a GF-cocktail treatment adapted from the literature. ${ }^{23}$ Indeed, the use of undifferentiated stem cells and the possible undesirable differentiation phenotypes that may arise after transplantation requires being cautious with this approach. This protocol gave rise to immature cardiac cells whose regeneration potential could be more effective than that exerted by fully differentiated cardiomyocytes. This is because, after transplantation, cardiac progenitor cells should maintain for a certain time their proliferation potential that allows them to repopulate in part the injured myocardium. In addition, we compared the effects of the GF treatment in combination with a co-substrate composed of FN and LM. We then showed how the ECM biomimetic coating, provided as a support by the PAMs and combined to the addition of a cocktail of GFs in the media, could favor the ADSC commitment into the cardiomyogenic lineage.

\section{MATERIALS AND METHODS \\ Materials}

Glycofurol (tetraglycol or $\alpha$-[(tetrahydro-2-furanyl)methyl]x-hydroxy-poly(oxy-1,2-ethanediyl), fibronectin, dimethyl sulfoxide (DMSO) and bovine serum albumin (BSA) were obtained from Sigma-Aldrich (Saint Quentin Fallavier, France). Polyvinyl alcohol (Mowiol 4-88) was obtained from Kuraray Specialities Europe (Frankfurt, Germany). Culture media, penicillin, streptomycin, and trypsin were obtained from Invitrogen (Cergy Pontoise, France). Uncapped (free carboxylic acid group at the terminal end) PLGA 37.5/25 was provided by Phusis (Saint-Ismier, France).

\section{Cardiac muscle commitment of ADSCs}

Primary cultures of ADSCs have been used (Lonza France, Levallois Perret, France). A phenotypic characterization of these cells, along with their differentiation potential, is certified by the company. To assess ADSC differentiation towards cardiomyocytes, culture-expanded cells were plated at a density of $1 \times$ $10^{3}$ cells $/ \mathrm{cm}^{2}$. Twenty-four hours later we added to cell culture a cocktail of several GFs and cytokines containing $2.5 \mathrm{ng} / \mathrm{mL}$ TGF- $\beta 1$ (Peprotech, Neuilly sur Seine, France), 50 ng/mL IGF-1 (Peprotech, France), 5 ng/mL BMP-2 (Peprotech, France), 10 ng/mL FGF-4 (Peprotech, France), 100 ng/mL IL-6 (Peprotech, France), $1000 \mathrm{U} / \mathrm{mL}$ LIF (Sigma, St Quentin Fallavier, France), $40 \mathrm{nM} \alpha$-thrombin, $10 \mathrm{ng} / \mathrm{mL}$ VEGF-A (Peprotech, France), $10 \mathrm{n} M$ retinoic acid (Sigma), supplemented with 3\% FBS, $100 \mathrm{U} / \mathrm{mL}$ penicillin, and $100 \mu \mathrm{g} / \mathrm{mL}$ streptomycin. Low serum conditions were used to better assess the effect of the GFs. Cells were harvested after 1 and 2 weeks and ADSCs cardiac commitment was assessed by qRT-PCR and immunocytochemistry. An enriched treatment by increasing TGF- $\beta 1$ concentration in the GF cocktail was also used to investigate its beneficial effects on ADSCs differentiation. Briefly, $10 \mathrm{ng} / \mathrm{mL}$ TGF- $\beta 1$ (Peprotech, France) was used in the enriched GF cocktail instead of the $2.5 \mathrm{ng} / \mathrm{mL}$ cited previously.

\section{Effect of ECM molecules on cardiac muscle commitment of ADSCs}

To assess the ECM molecule effects on ADSC differentiation towards cardiomyocytes, culture-expanded cells were plated 
TABLE I. Human Specific Cardiac Primers

\begin{tabular}{|c|c|c|c|}
\hline Gene & Full Name & NM Accession Number & Sequences \\
\hline GATA4 & GATA binding protein 4 & NM_002052.3 & $\begin{array}{l}\text { Fwd: AGATGCGTCCCATCAAGACG } \\
\text { Rev: GGAGCTGGTCTGTGGAGACT }\end{array}$ \\
\hline MEF2C & Myocyte enhancer factor $2 \mathrm{C}$ & NM_001131005.2 & $\begin{array}{l}\text { Fwd: CTAATCTGATCGGGTCTTCCTTCAT } \\
\text { Rev: TTTTTCTCCCCATAGTCCCCG }\end{array}$ \\
\hline Nkx2.5 & NK2 homeobox 5 & NM_004387.3 & $\begin{array}{l}\text { Fwd: CTATCCACGTGCCTACAGCG } \\
\text { Rev: GCCGCTCCAGTTCATAGACC }\end{array}$ \\
\hline SERCA2a & $\begin{array}{l}\text { ATPase, } \mathrm{Ca}^{++} \text {transporting, } \\
\text { cardiac muscle, slow } \\
\text { twitch } 2 \text { (ATP2A2) variant a }\end{array}$ & NM_001681.3 & $\begin{array}{l}\text { Fwd: ACCTGGAACCTGCAATACTGG } \\
\text { Rev: TGCACAGGGTTGGTAGATGTG }\end{array}$ \\
\hline MLC-2V & $\begin{array}{l}\text { Myosin light chain } 2 \text {, } \\
\text { cardiac, slow }\end{array}$ & NM_000432.3 & $\begin{array}{l}\text { Fwd: GATGGAGCCAATTCCAACGTG } \\
\text { Rev : ACGTTCACACGCCCAAGAG }\end{array}$ \\
\hline cTnl & Troponin I type 3 (cardiac) & NM_000363.4 & $\begin{array}{l}\text { Fwd CCTGCGGAGAGTGAGGATCT } \\
\text { Rev: CAGTGCATCGATGTTCTTGCG }\end{array}$ \\
\hline CX43 & $\begin{array}{l}\text { Gap junction protein } \\
\text { alpha } 1,43 \mathrm{kDa}\end{array}$ & NM_000165.3 & $\begin{array}{l}\text { Fwd: TCTGAGTGCCTGAACTTGCC } \\
\text { Rev: CACCTTCCCTCCAGCAGTTG }\end{array}$ \\
\hline
\end{tabular}

at a density of $1 \times 10^{3}$ cells $/ \mathrm{cm}^{2}$, each culture dish having been coated with $2.5 \mu \mathrm{g} / \mathrm{cm}^{2} \mathrm{FN}$ (Sigma), $1 \mu \mathrm{g} / \mathrm{cm}^{2} \mathrm{LM}$ (Sigma) or left uncoated, in DMEM, 3\% FBS culture medium. The cocktail of GFs was added to the cell culture $24 \mathrm{~h}$ later. Cells were harvested after 1 and 2 weeks and ADSC commitment was assessed by evaluating the expression of early and late cardiac markers by qRT-PCR and immunocytochemistry. The enriched treatment with increased concentration of TGF- $\beta 1(10 \mathrm{ng} / \mathrm{mL})$ in the GF cocktail was also used here.

\section{Formulation of PAMs}

In order to formulate $60 \mu \mathrm{m}$ PAMs, the organic solution (667 $\mu \mathrm{L} ; 3: 1$ methylene chloride: acetone) containing $50 \mathrm{mg}$ of a PLGA copolymer with a lactic:glycolic ratio of 37.5:25 (MW: 25,000 Da) (Phusis, Saint Ismier, France) was emulsified in a poly (vinyl alcohol) aqueous solution $(90 \mathrm{~mL}, 4 \%$ $\mathrm{w} / \mathrm{v}$ ) maintained at $1^{\circ} \mathrm{C}$ and mechanically stirred for $1 \mathrm{~min}$ (Heidolph RZR2041, Merck Eurolab, Paris, France) as previously described. ${ }^{41,42}$ After addition of $33 \mathrm{~mL}$ of deionized water and stirring for $10 \mathrm{~min}$, the resulting oil-in-water emulsion was added to deionized water (167 mL) and stirred at $550 \mathrm{rpm}$ further for $20 \mathrm{~min}$ to extract the organic solvent. Finally, the formed microparticles were filtered on a $5 \mu \mathrm{m}$ filter (HVLP type, Millipore SA, Guyancourt, France), washed with $500 \mathrm{~mL}$ of deionized water and freeze-dried.

In order to obtain PAMs presenting the biomimetic surface, a combination of ECM with the highly charged PDL (Sigma) molecules was used to favor cell attachment on PAMs surface. Briefly, the PLGA microspheres were coated as previously described ${ }^{35,38}$ with $12 \mu \mathrm{g} / \mathrm{mL}$ poly-D-lysine and $18 \mu \mathrm{g} / \mathrm{mL} \mathrm{FN}$ or LM, stirred for $90 \mathrm{~min}$ at $15 \mathrm{rpm}$ in an incubator, washed, freeze-dried, and stored at $4{ }^{\circ} \mathrm{C}$ for the in vitro experiments. The biomimetic surface of FN and LM was characterized after immunofluorescence as previously described. ${ }^{35,43}$

\section{Carrier effect of PAMs on cardiac muscle commitment of ADSCs}

Culture-expanded ADSCs were harvested and cultured under differentiating conditions with PAMs presenting either a FN
(FN-PAMs) or a LM (LM-PAMs) biomimetic surface. Briefly, $0.5 \mathrm{mg}$ of FN-PAMs or LM-PAMs were incubated with $2 \times 10^{5}$ ADSCs without any agitation in a 24-well ultra low attachment plate (Costar), in DMEM supplemented with the cocktail of GFs described above. The 3D cell/PAM complexes were observed throughout the 7 days of the study by light microscopy to control for the maintenance of the complexes. Cardiomyogenic commitment was assessed by qRT-PCR and immunocytochemistry.

\section{Primers design and validation}

A panel of cardiac genes, the transcription factors GATA binding protein 4 (GATA4), myocyte enhancer factor 2C (MEF2C), NK2 homeobox 5 (Nkx2.5), the sarcomeric ATPase, $\mathrm{Ca}^{++}$ transporting, cardiac muscle, slow twitch 2, variant a (SERCA2a), the cardiac myosin light chain 2 (MLC-2V), the cardiac troponin I (cTnI), and the gap junction protein alpha 1, connexin 43 (CX43/GJA1) have been used to study ADSC mRNA levels during the commitment (Table I, primers ordered from Eurogentec, Angers, France). The following experimental details were performed following the guidelines of the SCCAN core facility ("Service Commun de Cytométrie et d'Analyse Nucléotidique," Angers, France). Human sequences were determined using PubMed nucleotide search (www.ncbi.nlm. nih.gov) and Ensembl (www.ensembl.org) websites. The online freeware Primer blast (http://www.ncbi.nlm.nih.gov/ tools/primer-blast/) was used for primer modeling, clustalw (www.ebi.ac.uk) to align nucleotidic sequences, and nucleotide blast (www.ncbi.nlm.nih.gov) to confirm the specificity of the defined primer sequences. When possible, pairs of primers were designed across intron-spanning regions to avoid genomic DNA contamination. Sense and antisense desalted primer pairs (Eurogentec, Angers, France) were mixed in RNAse free water at a final concentration of $5 \mathrm{~m} M$ and specificity validated using cDNA from human adult or fetal heart and commercial qPCR Human Reference cDNA (Clontech, Takarabio, Saint-Germain-en-Laye, France). The melting peak of the amplicon had to be narrow and unique, and its size and specificity were confirmed by electrophoresis. Finally, a serial dilution of the PCR product was reamplified to draw a linear curve $\mathrm{Ct}=\mathrm{f}$ (Quantity). The efficiency of the primer was 
calculated from the slope of the linear curve: $E=\left[10^{(-1 /}\right.$ slope) -1$] \times 100$. Only primer pairs with an efficiency greater than $80 \%$ were validated for use (Table I).

\section{Real-time quantitative PCR}

ADSCs were detached using trypsin-EDTA (Sigma) and washed in DPBS. Following the manufacturer's guidelines, cells were lysed in a $1 \% \quad \beta$-mercaptoethanol containing buffer and RNA extracted following a treatment by DNAse to remove any traces of genomic DNA (total RNA isolation Nucleospins ${ }^{\circledR}$ RNA II, Macherey Nagel, Hoerdt, France). First strand cDNA synthesis was performed with a Ready-To-Go You-Prime First-Strand Beads ${ }^{\circledR}$ kit in combination with random hexamers (Amersham Biosciences, Orsay, France) using $1 \mu \mathrm{g}$ RNA according to the manufacturer's guidelines. Following first-strand cDNA synthesis, cDNAs were purified (Qiaquick PCR purification kit, Qiagen, Courtaboeuf, France) and eluted in $50 \mu \mathrm{L}$ RNAse free water (Gibco). Five microliters of cDNA (1:20) was mixed with iQ SYBR Green Supermix (Biorad) and primer mix $(0.2 \mathrm{mM})$ in a final volume of $15 \mu \mathrm{L}$. Amplification was carried out on a Chromo4 thermocycler (Biorad) with a first denaturation step at $95^{\circ} \mathrm{C}$ for 3 min and 40 cycles of $95^{\circ} \mathrm{C}$ for $10 \mathrm{~s}, 55^{\circ} \mathrm{C}$ for $15 \mathrm{~s}$, and $72^{\circ} \mathrm{C}$ for $15 \mathrm{~s}$. After amplification, a melting curve of the products determined the specificity of the primers for the targeted genes. A mean cycle threshold value (Ct) was obtained from two measurements for each cDNA. Several housekeeping genes, glyceraldehyde-3-phosphate dehydrogenase (GAPDH, NM_002046), hypoxanthine phosphoribosyltransferase 1 (HPRT1, NM_000194), $\beta$-actin (Actb,NM_001101), 30S ribosomal protein S18 (Rps18,NM_001093779) and heat shock $90 \mathrm{kDa}$ protein $1 \beta$ (Hspcb, NM_007355) were tested and the three best ones chosen for normalization. The relative transcript quantity $(Q)$ was determined by the $\Delta \mathrm{cT}$ method $Q=E^{(\mathrm{Ct} \text { mininall the samples tested }-\mathrm{Ct} \text { of the sample) }}$, where $E$ is related to the primer efficiency $(E=2$ if the primer efficiency $=100 \%$ ). Relative quantities $(Q)$ were normalized using the multiple normalization method described in Vandesompele et al. ${ }^{44}$

\section{Immunofluorescence}

Uninduced and induced cells were used for GATA4, Nkx2.5, MEF2C, cTnI, and CX43 immunocytofluorescence. After washing the slides three times with DPBS, cells were fixed with $4 \%$ paraformaldehyde at $4{ }^{\circ} \mathrm{C}$ for $15 \mathrm{~min}$ and then permeabilized with $0.2 \%$ TritonX 100 (Sigma) for 5 min. Slides were blocked with DPBS, 10\% normal goat serum (Sigma), $4 \%$ bovine serum albumin (BSA) (Sigma) at room temperature for $45 \mathrm{~min}$. After washing, slides were incubated overnight at $4^{\circ} \mathrm{C}$ with goat anti GATA4 (1:100, Abcam, Paris France), mouse anti-Nkx2.5 (1:200, Abcam), mouse anticTnI (1:100, Abcam), rabbit anti-MEF2C (1:100, Abcam) and rabbit anti-CX43/GJA1 (1:100) in DPBS, 4\% BSA, $0.2 \%$ TritonX-100. Isotypic controls were made with IgG1k (cloneMOPC-31C,\#557273,BD Biosciences) and IgG2bk (clone27 35,\#555740, BD Biosciences). After rinsing, the cells were incubated with the corresponding secondary biotinylated anti-mouse or anti-goat or anti rabbit antibody (1:200,
Abcys) in DPBS, 4\% BSA, $0.2 \%$ TritonX-100 for $1 \mathrm{~h}$. Finally, after rinsing again and following incubation with streptavidinFITC (1:500, Dako) or streptavidin-rhodamin (1:500, Dako) in DPBS for $40 \mathrm{~min}$, the slides were mounted (Mounting Media, Dako) and observed with a fluorescence microscope (Axioscop, Carl Zeiss, LePecq, France). All the pictures were calibrated and taken with the same intensity and exposition times using the metavue ${ }^{\circledR}$ bioimaging software. An estimation of fluorescence intensity was performed by image analysis using the Metamorph ${ }^{\circledR}$ software from at least three separated images and three independent experiments.

\section{Statistical analysis}

Data were expressed as mean \pm SEM. The values were analyzed using one-way ANOVA and Tukey Multiple Comparison Test as post-ANOVA test. Differences were considered significant for $p<0.05$.

\section{RESULTS}

\section{ADSC cardiac commitment with the cocktail of GFs}

We studied the expression of the main transcription factors that initiate the differentiation pathway toward the cardiomyocyte lineage (GATA4, Nkx2.5, MEF2C) ${ }^{45-47}$ and the expression of specific cardiac proteins (cTnI, SERCA2a, MLC$2 \mathrm{~V}$ ) in the ADSCs treated with the GF cocktail within 2 weeks. The investigated transcripts were only slightly detectable or not expressed in ADSCs under basal conditions without GFs after 1 and 2 weeks except for MLC-2V. After the GF treatment for 2 weeks GATA4 was highly expressed (29-fold increase compared with the first week) while the mRNA level of MEF2C did not significantly increase and Nkx2.5 was not expressed at all [Fig. 1(A)]. The GFs induced the mRNA expression of SERCA2a at week 2 (21-fold increase compared with the first week) while only a slight, not significant, increase of the mRNA level was observed for MLC-2V and the mRNA of cTnI was not expressed at all [Fig. 1(A)].

The immunofluorescence analysis suggest that the GF treatment increased the protein expression of GATA4 and cTnI at week 2 in respect to the control without GFs, as the merged fluorescence of the two corresponding fluorochromes shows in Figure 1(C). A bright staining of MEF2C was observed in correspondence to the nucleus of the treated ADSCs [Fig. 1(E)]. Since no transcripts were detected for both cTnI and MEF2C, we supposed that a transitory expression of these mRNAs occurred within the first week of the treatment leading to the biosynthesis of the corresponding proteins during the following week.

\section{ECM molecules further induce ADSC cardiac commitment}

To assess the influence of LM and FN in combination with the GF cocktail on the cardiac commitment of ADSCs, the mRNA expression of several cardiac markers was studied. For the qRT-PCR analysis we used GAPDH as a reference and ADSCs were treated for 1 and 2 weeks. At week 1 we did not observe any Nkx2.5 expression (data not shown), nor significant changes in GATA4 mRNA levels with FN, LM, 


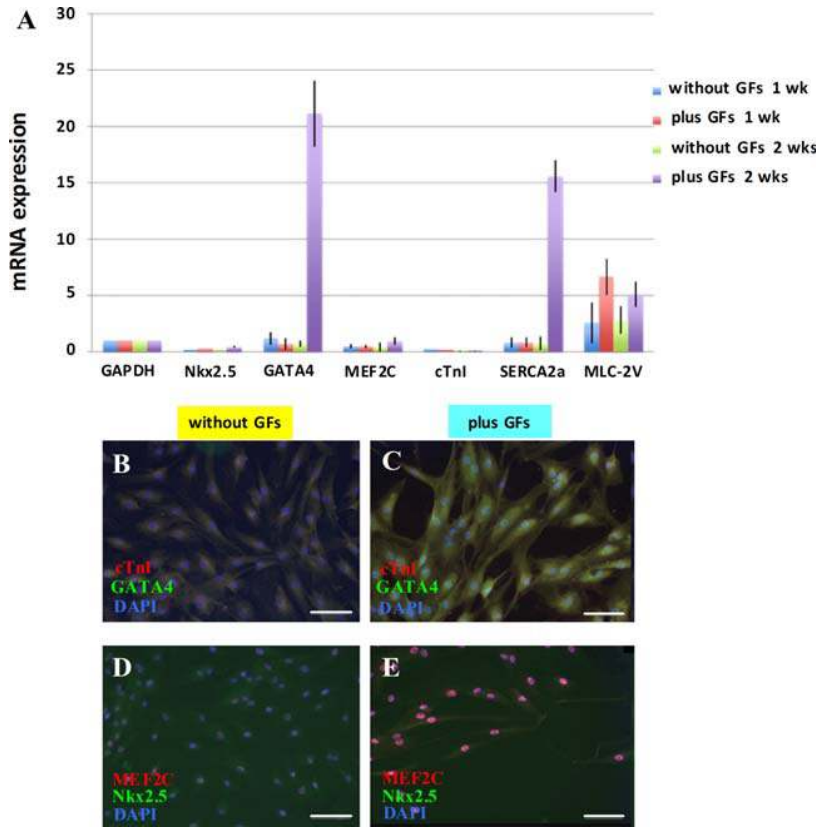

FIGURE 1. Cardiac muscle commitment of ADSCs treated with GFs. (A) One week of treatment with the GF cocktail did not significantly increase the mRNA expression of the early and late markers of cardiac commitment in ADSCs cultured on uncoated dishes. After 2 weeks of treatment the transcript levels of GATA4 and SERCA2a were higher than the corresponding groups at week 1. The mRNA levels of MLC-2V increased after 1 and 2 weeks of treatment but without reaching the statistical significance. Transcripts of Nkx2.5, MEF2C, and cTnl were almost not detectable under all conditions. Values represent the mean \pm SEM of four separated experiments $(n=4)$ and are expressed as arbitrary units obtained with qRT-PCR and normalized to GAPDH set at $1 .{ }^{*} p<0.001$ vs. all other groups. The immunocytochemistry analysis performed in ADSCs cultured for 2 weeks (B-E) shows the merged fluorescence of different dyes, including the nuclear blue counterstaining obtained with DAPI. Scale bars correspond to $100 \mu \mathrm{m}$. The expression of cTnl (rhodamin), GATA4 (FITC), Nkx2.5 (FITC), and MEF2C (rhodamin), were evaluated in the absence (B, D) or presence (C, E) of the GF cocktail. The micrographs show that the protein expression of GATA4, MEF2C, and cTnl, but not Nkx2.5, was detectable after 2 weeks of GF treatment. [Color figure can be viewed in the online issue, which is available at wileyonlinelibrary.com.]

GFs alone or with the combination of FN (GF-FN) (Fig. 2). Importantly, GATA4 was very highly expressed in the GF-LM condition (450-fold increase compared with the GAPDH mRNA expression), suggesting an early engagement towards a cardio-muscular lineage. Furthermore, in the same conditions the mRNA of MEF2C (10-fold increase) and SERCA2a (sixfold increase) were highly expressed. At week 2 only a weak presence of GATA4 mRNA was still observed (twofold increase), suggesting a transitory expression of these latter factors (data not shown).

The double immunostaining revealed that only the transcription factor MEF2C was expressed and was located in the cytoplasm when cells are cultivated on FN supplemented with the GF cocktail for 1 week [Fig. 3(A)]. Interestingly, at week 2 in the same conditions, $\mathrm{Nkx} 2.5$ was found in the cytoplasm [Fig. 3(B)], a nuclear translocation of MEF2C likely occurred [Fig. 3(B), arrows in the inset], and GATA4 was highly expressed [Fig. 3(E)]. At this time-point however, cTnI, which normally appears later in the differen- tiation process of cardiomyocytes, was not found using FN [Fig. 3(E)]. When cells were cultured on a LM coating, Nkx2.5 was found at both time-points in the cytoplasm [Fig. $3(C, D)]$. In addition, MEF2C appears to be already in the nucleus of some cells the first week and to remain in the same compartment at week 2 in the majority of the cells [Fig. 3(C,D)]. Moreover, using the LM substrate, both GATA4 and cTnI were observed at 2 weeks [Fig. 3(F)], suggesting that this ECM molecule better induces the cardiogenic differentiation of ADSCs. Finally, using a cell proliferation assay (Cyquant ${ }^{\circledR}$ Invitrogen), a higher number of cells with FN compared with LM were measured (data not shown).

GFs enriched in TGF- $\beta 1$ induce ADSC differentiation into immature cardiomyocytes

Since the TGF family is strongly involved in cardiomyogenesis, we hypothesized that TGF- $\beta 1$ would have improved the cardiac commitment of our cells as suggested by the literature. $^{7,48,49}$ To assess the influence of the increase in TGF- $\beta 1$ concentration on ADSC differentiation, the protein expression of several cardiac markers was studied after 2 weeks of treatment with GF-LM or under the same conditions enriched in TGF- $\beta 1$ (GF-TGF $\beta 1$ ) (Fig. 4). After the treatment with GF-LM we observed the presence of MEF2C, GATA4 and CTnI, while Nkx2.5 was only slightly expressed [Fig. 4(B,E) compared with Fig. 4(A,D)]. Interestingly, some cells appeared to express MEF2C and GATA4 within their nucleus, suggesting that these transcriptional factors were translocated from the cytoplasm to the DNA location [Fig. $4(\mathrm{~B}, \mathrm{E})$; inset]. When we combined GF-LM with a higher concentration of TGF- $\beta 1$, the biosynthesis of MEF2C and cTnI

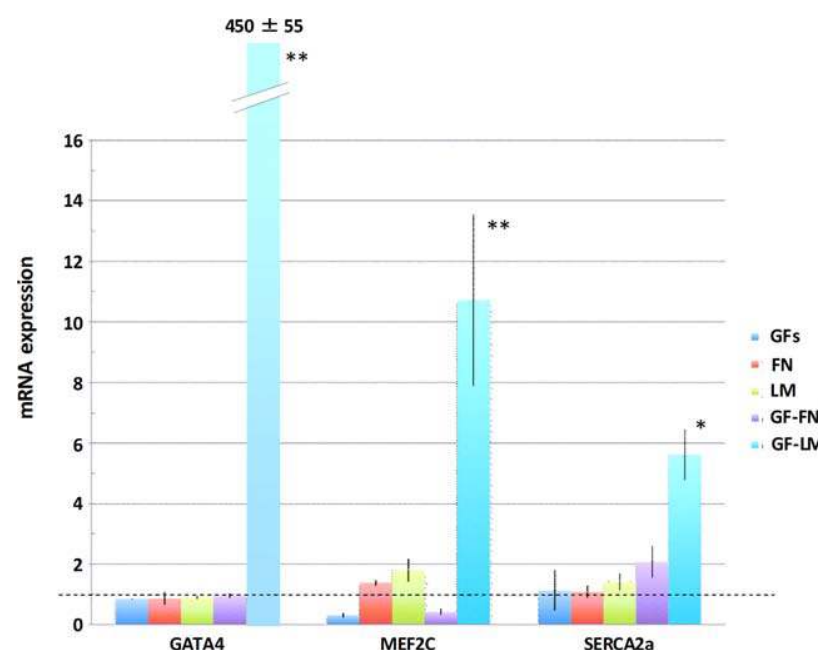

FIGURE 2. Effect of ECM molecules on transcript expression in ADSCs treated with GFs. GATA4, MEF2C, and SERCA2a transcription increased significantly in ADSCs cultured under GF-LM conditions while only slight, not significant, increases were observed under the other conditions. The mRNA values represent the mean \pm SEM of four separated experiments $(n=4)$ and are expressed as arbitrary units obtained with qRT-PCR normalized to GAPDH (dotted line $=1$ ). ${ }^{*} p<0.05$ and ${ }^{*} p<0.001$ vs. all other groups. [Color figure can be viewed in the online issue, which is available at wileyonlinelibrary. com.] 
1 week
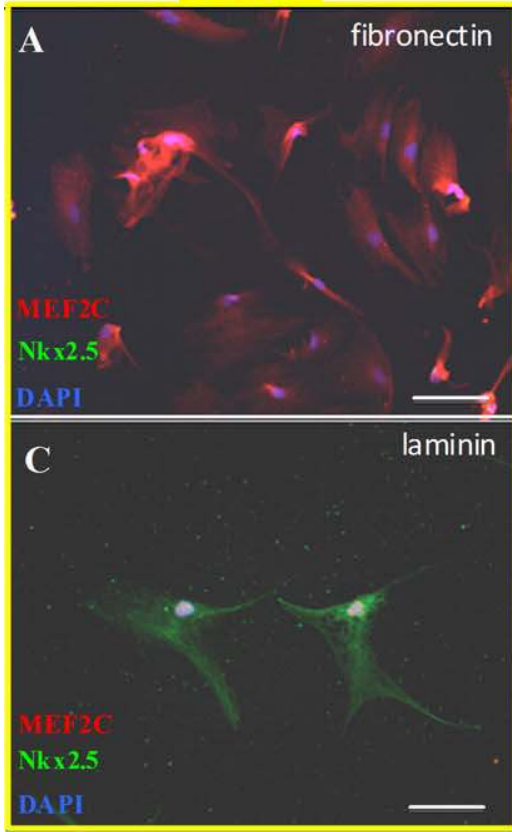

2 weeks
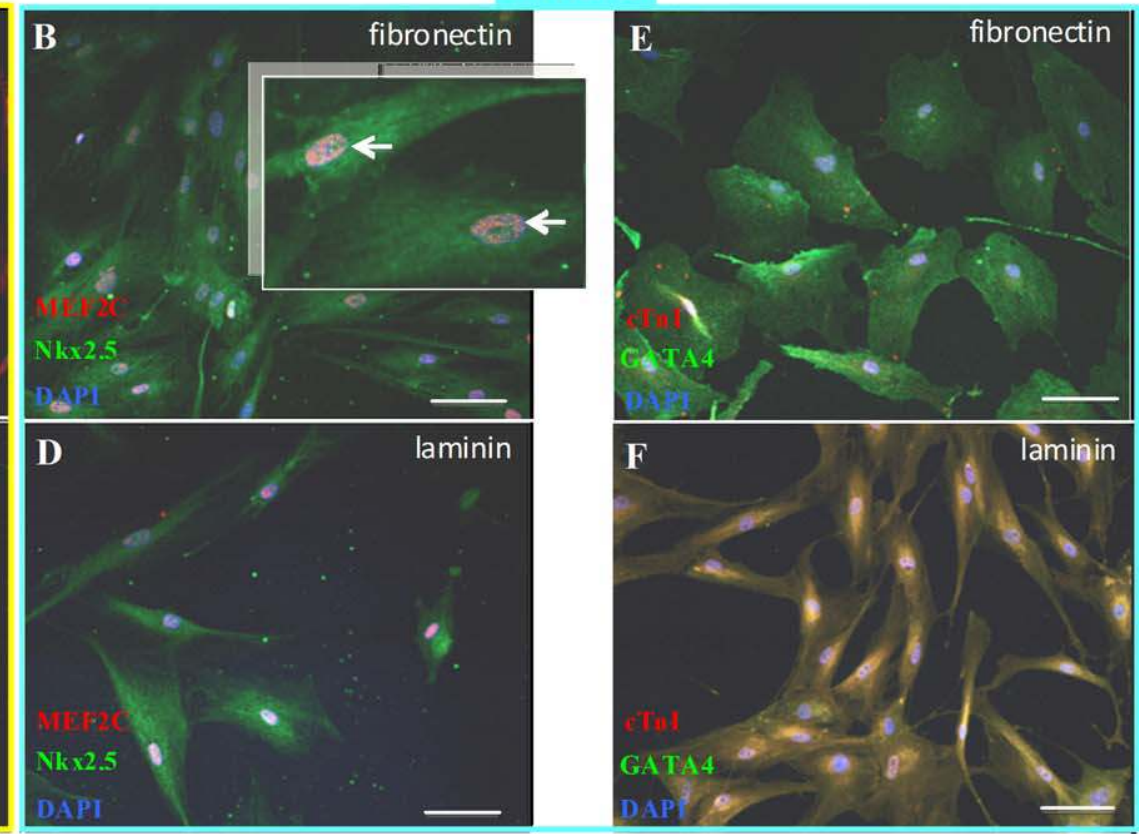

FIGURE 3. Immunofluorescence of cardiac muscle markers in ADSCs cultured with GFs on FN- or LM-coated dishes. The micrographs show the immunofluorescence of cells cultured on FN at week $1(A)$ and week $2(B, E)$, and on LM at week $1(C)$ and week $2(D, F)$, in the presence of the GF cocktail. The blue color (DAPI staining) indicates cell nuclei and all images represent the merging fluorescence of the different dyes. Scale bars correspond to $100 \mu \mathrm{m}$. ADSCs cultured for 1 week on FN expressed cytoplasmic MEF2C (rhodamin) (A) while, at this time-point, in the presence of LM its expression appeared to be already localized in the nucleus (C). In the second week, MEF2C seemed to translocate into the nucleus of the ADSCs cultured on FN (B, inset) as well as it was maintained in this cell compartment using LM (D). Nkx2.5 (FITC) was only expressed at week 2 using FN (B) while it was already expressed with LM after 1 week (C). GATA4 (FITC) was expressed in cells treated either with GF-LM or GF-FN at week 2 (E, F), while cTnl (rhodamin) was only expressed under GF-LM conditions (F). Taken together, these results suggest that LM, in combination with GF cocktail, enhanced the extent of most cardiac markers expression better than FN. [Color figure can be viewed in the online issue, which is available at wileyonlinelibrary.com.]

further increased whilst GATA4 was very slightly expressed and Nkx2.5 not produced at all [Fig. 4(C,F)].

\section{PAMs potentiate ADSC cardiac muscle commitment}

To further provide a 3D structure to the cells we cultured ADSCs on PAMs with a LM or FN biomimetic surface for 1 week in combination with the cocktail of GFs or with that enriched in TGF- $\beta 1$. PAMs of an average diameter of $59.3 \pm 20$ showed a homogeneous distribution of the FN or LM biomimetic surface (Supporting Information Fig. 1). Most seeded cells adhered onto FN-PAMs and LM-PAMs and formed 3D-complexes that were maintained throughout time (Supporting Information Fig. 1). Although cell number may decrease at first, cell proliferation then increases their number, as previously reported with adult stem cells. ${ }^{35,36,43}$

The protein expression profiles of cardiac markers by ADSCs on FN-PAMs and LM-PAMs treated with the GF cocktail were compared (Fig. 5). This was possible because both FN-PAMs and LM-PAMs did not show aspecific staining. We verified that on the $3 \mathrm{D}$ support, FN did not have a better effect than LM [Fig. 5(B,D) compared with Fig. 5(E,F)]. In the latter condition Nkx2.5, GATA4, MEF2C and also cTnI were expressed. Table II summarizes ADSC protein expression and offers a comparative protein profile between the 2D and 3D culture conditions after 1 week. However, since it was difficult to compare 2D versus 3D data only speculative evaluations could be performed. We observed that in both FN- and LM-3D culture conditions, the protein expression appears to be higher than in 2D, especially those of GATA4 and MEF2C.

After having confirmed that a LM biomimetic surface is appropriate for the ADSC commitment on PAMs, we then studied the effect of the GF-TGF $\beta 1$ cocktail in combination with LM-PAMs. The expression of Cyclin D1 was also studied to evaluate whether the cells progress in cell cycle and proliferate rather than differentiate. We obtained similar mRNA expression of Cyclin D1 and SERCA2a in both control (LM-PAMs only) and differentiating conditions (LM-PAMs with GF or LM-PAMs with GF-TGFß1) (Fig. 6). The mRNAs of GATA4, Nkx2.5, and cTnI were not detected after 1 week in all conditions. On the contrary, at the same time-point, MEF2C expression was higher with LM-PAMs in GF-TGF $\beta 1$ conditions when compared with LM-PAMs with the GF cocktail only (twofolds compared with 1.7-folds). Additionally, the mRNA of CX43 was also expressed with the GF-TGF $\beta 1$ cocktail compared with the other conditions (1.5-folds compared with 1.2-folds for GF-PAMs). Although some differences were observed between the three conditions, the protein expression levels are probably masked by the strong 3D effect observed with PAMs. 

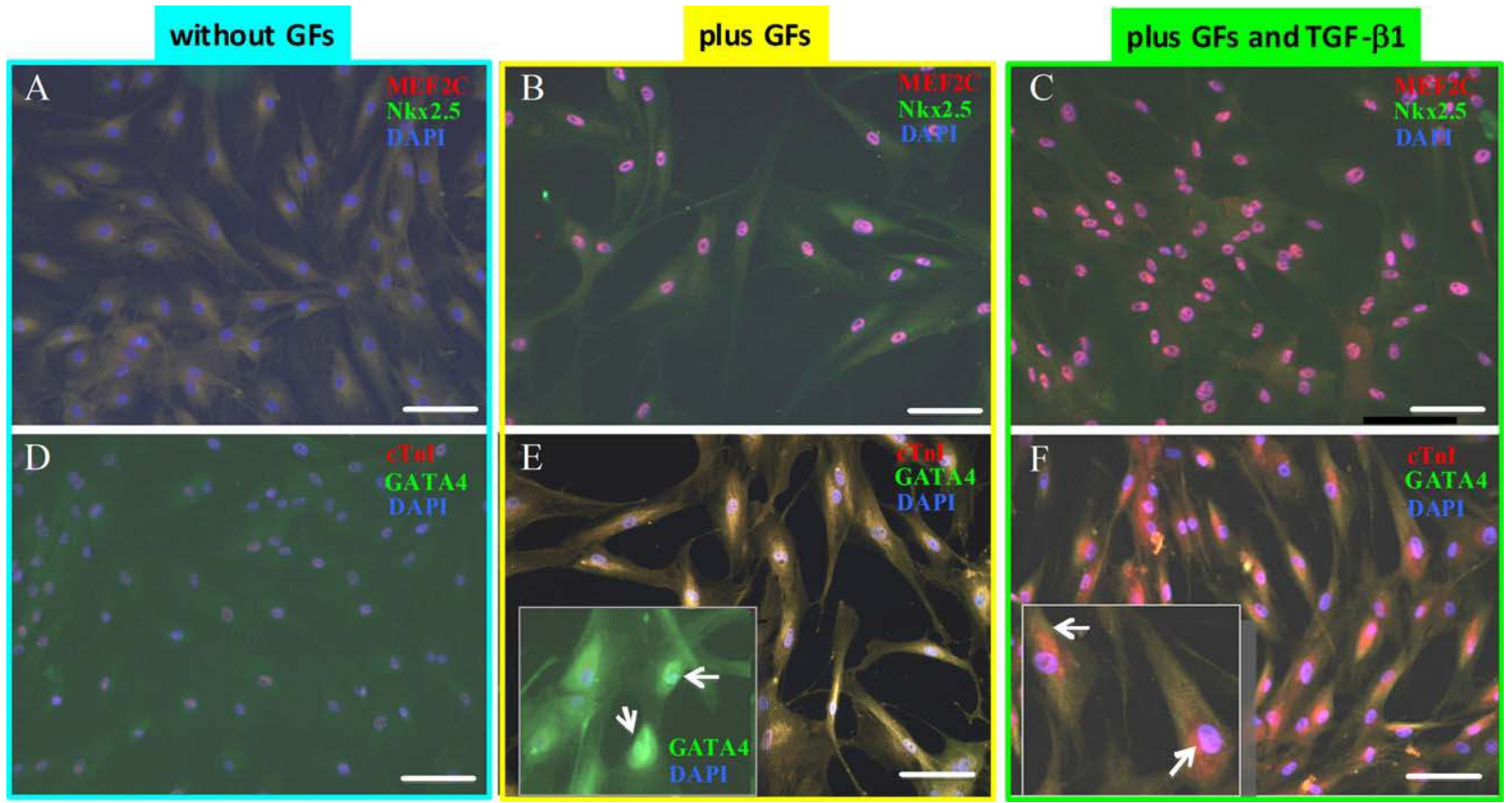

FIGURE 4. Cardiac marker expression in ADSCs cultured on LM and treated with the GF-TGF $\beta 1$ cocktail. Immunofluorescence shows the ADSCs cultured for 2 weeks on LM in the absence (A, D) or presence (B, E) of the GF cocktail, or in the presence of the GF-TGF- $\beta 1$ cocktail (C, F). The blue color indicates cell nuclei and all images represent the merging fluorescence of the different dyes. Scale bars correspond to $100 \mu$ m. Without GFs there was no relevant protein expression (A, D), while GATA4 (FITC), MEF2C (rhodamin), and cTnl (rhodamin) were significantly expressed in the presence of GFs (B, E) and further stimulated by the GF-TGF $\beta 1$ cocktail $(C, F)$. MEF2C appears to be localized in the nucleus ( $B$, C) as well as some GATA4 positive cells (arrows in the E inset, F). The arrows of the inset in (F) show that cTnl staining was not localized within the nucleus. Taken together, these results demonstrate that the expression of some cardiac marker in ADSCs cultured on LM with the GF cocktail can be further stimulated by increasing the concentration of TGF- $\beta 1$. [Color figure can be viewed in the online issue, which is available at wileyonlinelibrary.com.]

Concerning the protein expression analyzed by immunofluorescence, MEF2C and Nkx2.5 [Fig. 7(A)], GATA4 and cTnI [Fig. 7(B)], and CX43 [Fig. 7(F)] were all expressed by at least some ADSCs when cultured on LM-PAMs with the GF-TGF $\beta 1$ cocktail at week 1. Surprisingly, cell proliferation was observed at the center of the ADSC-PAM complexes where Ki67-positive cells were found [Fig. 7(D)], although DAPI stained cells were evenly distributed within the complexes [Fig. $7(\mathrm{C})$ ]. Due to its 3D conformation, a confocal microscopy observation was performed to better evaluate the distribution of the late cardiac differentiation markerexpressing cells within the ADSC-PAM complexes. Interestingly, the results revealed that cTnI was only expressed at the surface of the ADSC-PAM complexes while CX43 was also found within the complexes. The cells at the surface of the complexes co-expressed cTnI and CX43 [Fig. 7(E-H)].

\section{DISCUSSION}

In this study, a set of recombinant GFs was first applied to induce ADSC differentiation into immature cardiomyocytes. We observed that the pre-treatment of ADSCs for 2 weeks with the GF cocktail seemed to stimulate the translocation within the nucleus of MEF2C and enhanced the mRNA level of SERCA2a and MLC-2V, indicating that MEF2C could induce the transcription of SERCA2a and MLC-2V as already reported. ${ }^{50,51}$ Similar results have been described using
MSCs and a cocktail of GFs, as documented by the expression in the cytoplasm of the main transcription factors of the master cardiac genes after 5 days of treatment and their nuclear translocation after 20 days. ${ }^{23}$ In other studies, the effect of GFs was more pronounced on cardiac differentiation of MSCs and ADSC subpopulation,,52 because some end-stage proteins were also expressed and beating cardiomyocytes were obtained. By contrast, in our study, the ADSCs exposed to the GF cocktail at low serum conditions showed a less mature cardiac phenotype. In the aforementioned studies very high percentages of serum were used (20\% and $15 \%$, respectively) which probably further enhanced the actual GF cocktail differentiating effect.

It has also been demonstrated that ADSC differentiation towards the cardiac lineage was improved in vitro in the presence of LM. ${ }^{8}$ However, their differentiation was achieved through the administration of 5-azacytidin which cannot be used in the clinical setting. Furthermore, LM has been described to increase from the third day post-MI ${ }^{33}$ but no further studies were performed in vivo to investigate its possible role on cardiac repair. We here showed that the use of a LM substrate combined to the GF cocktail is important for the engagement of ADSCs into the cardiac lineage, as a cascade of events occurred starting from the expression of the earlier cardiac transcription factors Nkx2.5, GATA4, and MEF2C and followed by the expression of one of the targets of MEF2C, the sarcomeric protein $\mathrm{CTnI}^{53-56}$ Indeed, 


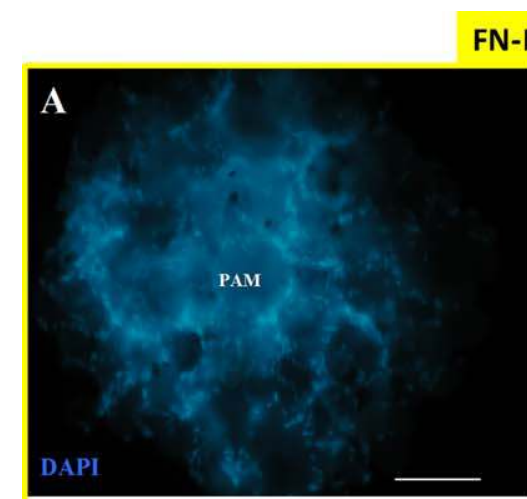

FN-PAMs
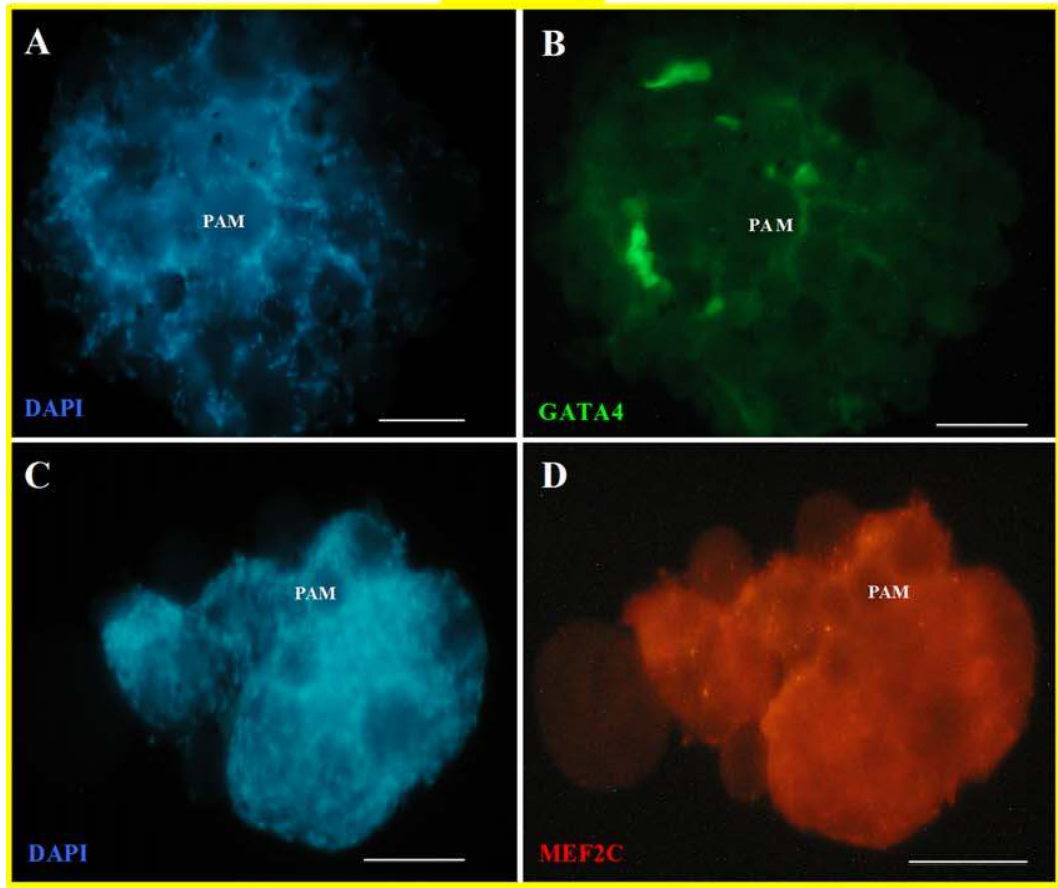

D

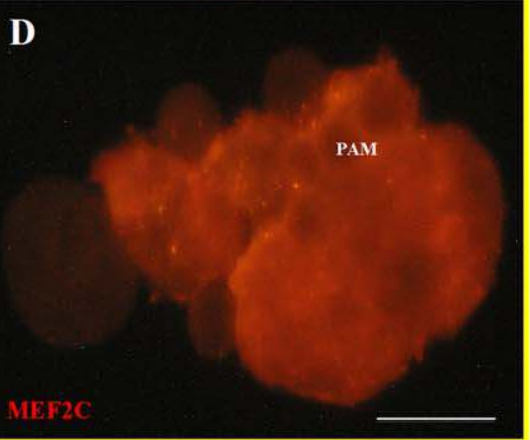

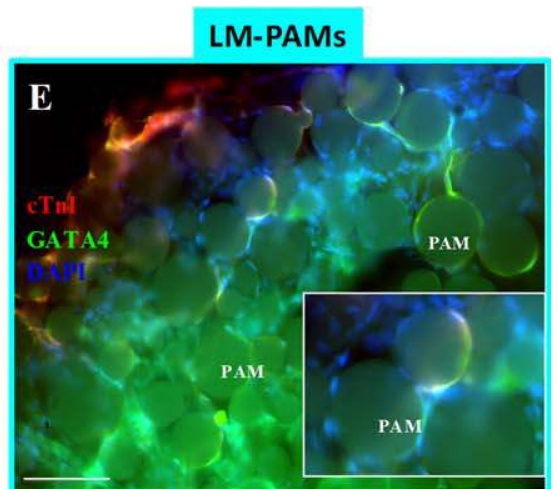

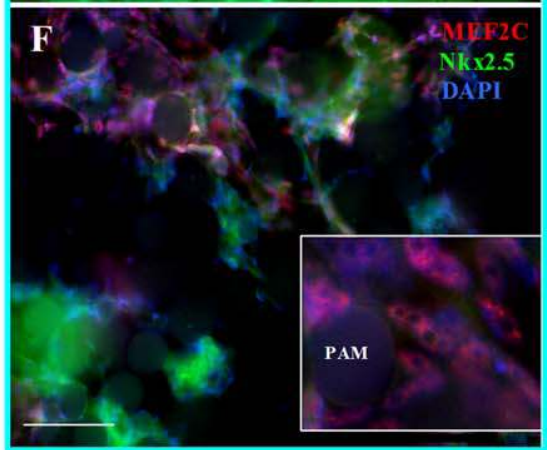

FIGURE 5. Cardiac muscle commitment of ADSCs treated with GFs and adhering to coated PAMs. PAMs potentiated ADSC cardiac muscle commitment as shown by the immunofluorescence of cells adhered on FN-PAMs (A-D) and LM-PAMs (E, F) when treated with the GF cocktail for 1 week. The DAPI staining indicates cell nuclei (A, C, E, F) and scale bars represent $100 \mu \mathrm{m}$. The expression of GATA4 (FITC) and MEF2C (rhodamin) was observed on FN-PAMs (B and D, respectively) and LM-PAM (E and F, respectively). cTnl (rhodamin) and Nkx2.5 (FITC) were also produced in ADSCs cultured on LM-PAMs (E and F, respectively). The inset in (E) better shows the localization of GATA4-expressing cells and the magnification in $(F)$ suggest the nuclear localization of MEF2C in some ADSCs. [Color figure can be viewed in the online issue, which is available at wileyonlinelibrary.com.]

GATA4 and Nkx2.5 are mutual cofactors considered as the key regulators of cardiomyogenesis, ${ }^{57}$ which interact with a third transcription factor MEF2C. These cofactors are necessary to induce the differentiation pathway into cardiomyocytes and the expression of late-stage differentiating proteins such as cTnI. By contrast, we did not observe these steps with FN, likely because of the lack of Nkx2.5 and the permanent cytoplasmic localization of MEF2C that did not allow reaching this degree of differentiation.

TGF- $\beta 1$ is known to favor the cardiomyogenic differentiation of human MSCs and rat ADSCs in vitro. ${ }^{7,58}$ Recently, a TGF- $\beta 1$ effect on cardiomyogenic differentiation was also demonstrated in the rat infarcted heart. ${ }^{59}$ An increase in the percentage of cardiac myosin heavy chain (MHC), connexin43 , and $\alpha$-sarcomeric actin positive cells, was observed 4 weeks after transplantation of bone marrow mononuclear cells (BMMNCs) embedded with poly (lactic-co-glycolic) nanospheres releasing TGF- $\beta 1$ within a fibrin gel (compared with control BMMNCs). In this sense, we investigated the effect of higher TGF- $\beta 1$ concentrations in the GF cocktail to know whether it could potentiate differentiation. In our study, TGF- $\beta 1$ was always present in the GF cocktail, but by increasing its concentrations we could potentiate the expression of GATA4 and MEF2C. Interestingly, some cells showed GATA4 within the nucleus indicating its translocation from the cytoplasm. Nevertheless, we did not find

TABLE II. Comparative Protein Expression Between the 2D and 3D Culture Condition After 1 Week of Treatment

\begin{tabular}{|c|c|c|c|c|c|}
\hline & Conditions & Nkx2.5 & GATA4 & MEF2C & cTnl \\
\hline \multirow[t]{5}{*}{$2 \mathrm{D}$} & Cells alone & - & - & - & - \\
\hline & FN coating & - & - & - & - \\
\hline & LM coating & - & - & - & - \\
\hline & Cocktail GF + FN coating & - & \pm & + & - \\
\hline & Cocktail GF + LM coating & + & \pm & + & - \\
\hline \multirow[t]{2}{*}{$3 \mathrm{D}$} & $\begin{array}{l}\text { Cocktail GF + PAM with a FN } \\
\text { biomimetic coating }\end{array}$ & ND & + & ++ & ND \\
\hline & $\begin{array}{l}\text { Cocktail GF + PAM with a LM } \\
\text { biomimetic coating }\end{array}$ & \pm & ++ & ++ & \pm \\
\hline
\end{tabular}

We observed that in both 3D culture conditions, the protein expression of GATA4 and MEF2C were higher than in 2D culture condition. However, because of the difficulty to compare 2D vs. 3D data, these tables can be considered only for speculative evaluations. ND, not done. 


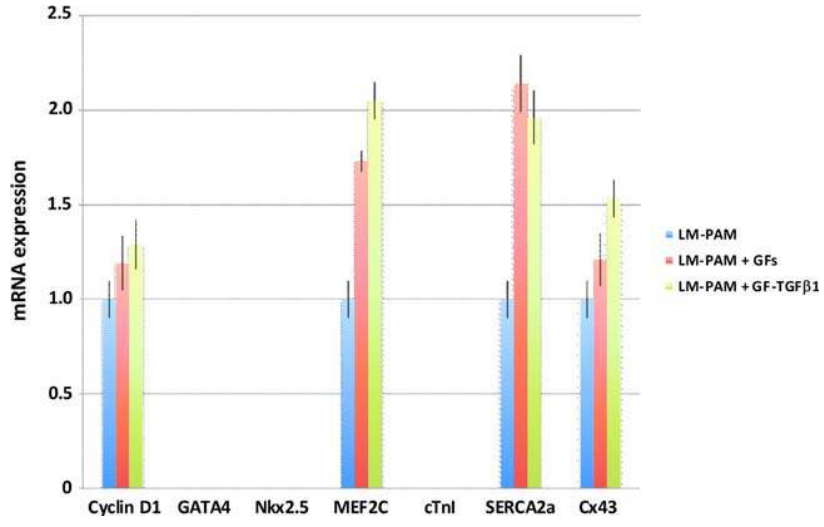

FIGURE 6. mRNA expression of cardiac markers in ADSCs cultured on LM-PAMs with the GF-TGF $\beta 1$ cocktail. The RT-PCR analysis was performed after 1 week of cell treatment with the GFs or the GF-TGF $\beta 1$ cocktail. Similar mRNA expression of Cyclin D1 and SERCA2a were observed in both control (LM-PAMs only) and differentiating conditions (LM-PAMs with GF or LM-PAMs with GF-TGF $\beta 1$ ). The mRNA levels of MEF2C and CX43 were increased using the GF-TGF $\beta 1$ cocktail when compared with LM-PAM both in the absence or presence of GFs. Transcripts of GATA4, Nkx2.5, and cTnl were not detectable under all conditions. Values represent the mean \pm SEM of two independent experiments in triplicate and are expressed as arbitrary units obtained with qRT-PCR normalized to GAPDH. [Color figure can be viewed in the online issue, which is available at wileyonlinelibrary. com.]

either Nkx2.5 or cTnI, suggesting that TGF- $\beta 1$ could increase the expression of only some transcription factors and participate to cardiac commitment through GATA4 nuclear translocation. Another study, applying a GF cocktail on MSCs in vitro, showed the role of TGF- $\beta 1$ in increasing Nkx2.5 and MEF2C cytosolic expression but without affecting their nuclear translocation. This work mentioned the implication of IGF-1, which is one of the components of the GF cocktail, in the nuclear translocation of the transcription factors. However, the concomitant role of TGF $\beta 1$ and IGF-1 in cardiac differentiation needs to be explored. The combination of LM and GFs cocktail, supplemented with higher TGF- $\beta 1$ concentrations, increased the expression of cytoplasmic cTnI and the apparent migration of MEF2C at nuclear level, but there was no or very slight production of Nkx2.5. However, Nkx2.5 and GATA4 can independently participate to cardiomyocytes differentiation, and have the ability to induce cardiac commitment even alone. ${ }^{60,61}$ This could explain why we obtained cTnI expression in the absence of Nkx2.5.

ADSC differentiation before transplantation might be beneficial if a homogenous population of cells can be obtained. However, in cardiac cell therapy the fibrotic scar, the lack of adhesion signals, and the loss of contact between the cells and the ECM molecules do not allow good cell engraftment within the damaged heart. The use of 3D supports covered by ECM molecules appears to be a reliable strategy to deliver cells and tissue-like structures. This approach might increase cell delivery efficiency and reduce cell death, optimizing engraftment efficacy and transplanted cell function. In order to implement the PAMs developed in our laboratory for cardiac cell therapy, we investigated
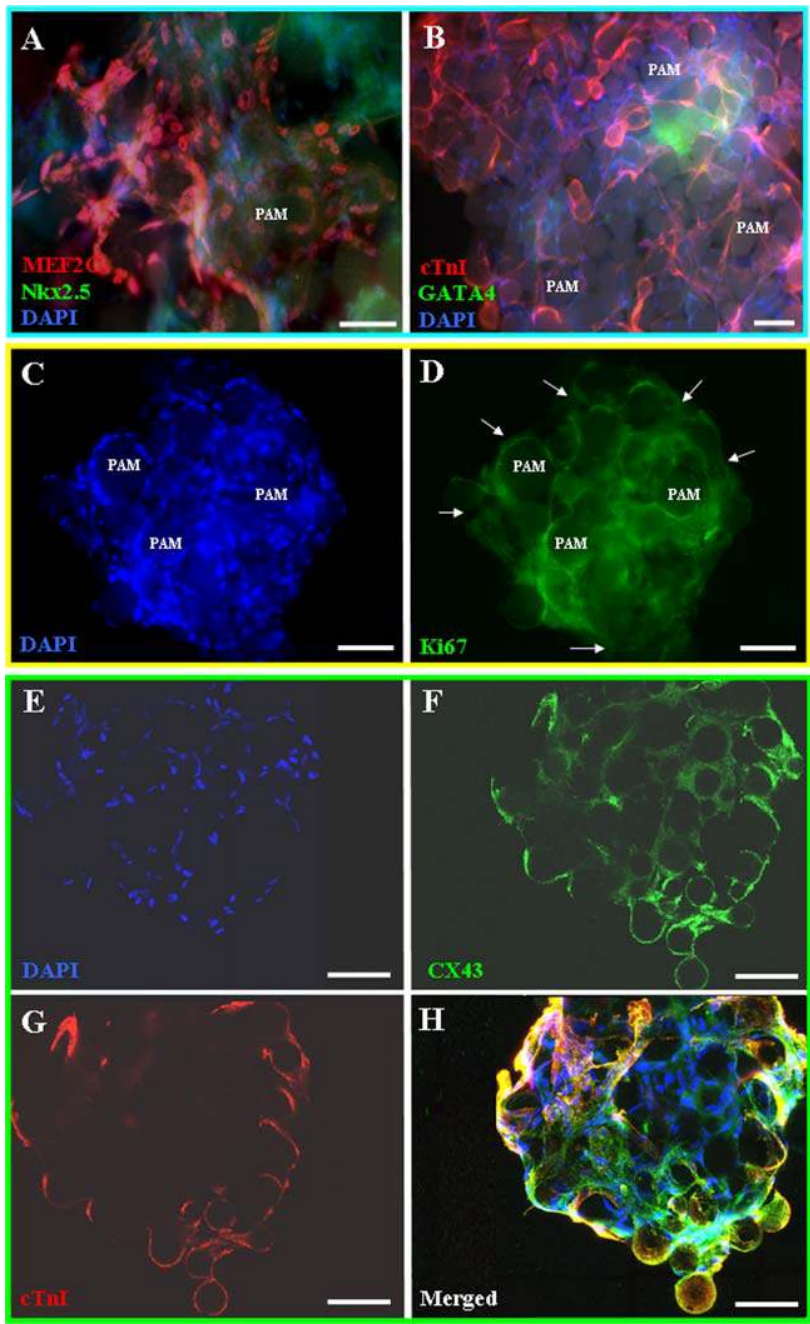

FIGURE 7. Immunofluorescence of cardiac muscle markers expressed by ADSCs embedded in LM-PAM complexes and treated with the GFTGF $\beta 1$ cocktail. The immunofluorescence analysis was performed in ADSCs adhered to LM-PAMs after 1 week of cell treatment with the GF-TGF $\beta 1$ cocktail. A, B, and $H$ are fluorescence-merged images and the blue staining (DAPI) indicates cell nuclei. Scale bars represent 100 $\mu \mathrm{m}$. Under these conditions, MEF2C (rhodamin) and Nkx2.5 (A), cTnl (rhodamin) and GATA4 (FITC) (B), and Ki67 (FITC) (D) were expressed, although the staining of Nkx2.5 and GATA4 was not present in all cells. Ki67 was mainly localized at the center of the complex as shown by the absence of its staining at the periphery of the aggregates (arrows in D to be compared with $\mathrm{C}$ ). Confocal observations were also performed on ADSC/LM-PAM complexes after 1 week treatment with GF-TGF $\beta 1(\mathrm{E}-\mathrm{H})$ showing that $\mathrm{CX} 43$ (FITC) (F) and $\mathrm{cTnl}$ (rhoda$\min )(G)$ were also expressed under these conditions. In particular, CX43- and cTnl-positive cells were localized at the surface of the ADSC/LMPAM complexes $(H$, merging). [Color figure can be viewed in the online issue, which is available at wileyonlinelibrary.com.]

whether these 3D supports could influence this differentiating process in vitro. Others authors demonstrated the role of LM in the cardiac lineage engagement of ESCs in 3D structure. They investigated the effect of 3D constructs and matrix composition on control and guidance of ESCs growth and differentiation in vitro. It was observed that the presence of FN in 3D collagen constructs strongly stimulated endothelial cell differentiation and vascularization, while LM 
increased the ability of ESCs to give rise to beating cardiomyocytes. ${ }^{62}$ Similarly, our results suggested that the 3D condition established by LM-PAMs was better than the 2D standard culture condition to induce the cardiac commitment in ADSCs, as GATA4, MEF2C, and cTnI appeared more highly expressed. Moreover, LM-PAMs seemed to be better inductors of cardiac differentiation than FN-PAMs. Since the mRNAs of GATA4, Nkx2.5, and cTnI were not present at the same time, we suppose that they were transcribed earlier and then degraded.

By combining the enriched GF-TGF- $\beta 1$ cocktail with LMPAMs, we found that the mRNA levels of MEF2C and CX43 were increased compared with the GF cocktail LM-PAM conditions. Furthermore, we observed the presence of all the studied transcription factor proteins but also that of more mature cardiac proteins, such as SERCA2a, cTnI, and CX43, demonstrating the progression of ADSCs cardiac differentiation. Some ADSCs stained positive for Ki67 indicating that they continued to proliferate, which was confirmed by the presence of cyclin D1. Moreover, the Ki67-positive cells were localized within the PAM-ADSCs complexes and not at the periphery, suggesting that the pool of potentially growing undifferentiated cells remained at the center of the complexes where there is a poor GF diffusion gradient and also less oxygenation which maintains ADSC "stemness."63,64 However, this hypothesis needs to be further confirmed. Interestingly, cTnI-positive cells were localized at the surface of the ADSC-PAM complexes, while an expression gradient was observed for CX43, the cells with the higher expression levels situated also at the periphery as shown by confocal microscopy analysis.

Gap junctional coupling is essential in establishing electrochemical communication between cardiomyocytes. These structures consist of two hexameric assemblies of connexin proteins embedded in the plasma membranes of neighboring cells, thereby forming the so-called connexon hemichannels. CX43, the major gap junction protein of the working myocardium is involved in cardiac development by transferring cardiomyogenic signals between cardiomyocytes. ${ }^{65,66}$ Lack of such a protein results in serious cardiac malformation during development and is correlated to the arrhythmic phenomenon encountered following cell transplantation. ${ }^{66-68}$ Our results suggest that TGF- $\beta 1$ increased CX43 expression in ADSC-LM-PAMs complexes. The role of TGF- $\beta 1$ on CX43 expression of smooth muscle cells has been already investigated. ${ }^{69}$ It was demonstrated that TGF$\beta 1$ up-regulated CX43 expression and intercellular communication, in concert with the increased expression of $\alpha$-actin, calponin, and smooth muscle heavy chain isoform 1, thus indicating the role of this growth factor in improving CX43-mediated gap-junction communication and enhancing contractile activity. ${ }^{69}$ The presence of CX43-expressing cells in ADSC-PAM complexes represents a further advantage for cell therapy, as it should allow a better ADSCs engraftment and communication with host cells. Additionally, it has been described recently that injection of CX43 mimetic peptides has a protective effect against myocardial infarction, particularly on cell death and infarct size reduction, ${ }^{70}$ suggesting that our CX43-expressing cells could also participate to infarct size reduction and cell survival.

In conclusion, these results suggest that ADSCs are able to express both early and late cardiac muscle markers when treated with a cocktail of GFs and LM under 2D conditions. The 3D support offered by PAMs in combination with the LM biomimetic coating and the GFs cocktail improve the biosynthesis of cardiac markers and the supplementation of TGF- $\beta 1$ potentiates their expression. The presence of CX43 in treated ADSCs also suggests the possibility of communication between these cells. Taken together, these findings let us hypothesize that PAMs conveying cardiac committed ADSCs and releasing TGF- $\beta 1$ may increase, in the post-MI region, their survival and differentiation and favor cell communication with hosted cells, allowing a better process of myocardial regeneration and recovery of cardiac function. On the contrary, the high number of GFs which are present in our cocktail cannot be encapsulated into PAMs but used to prime ADSCs toward cardiomyogenesis before their injection.

\section{ACKNOWLEDGMENTS}

The authors thank the SCIAM ("Service Commun d'Imagerie et d'Analyse Microscopique") of Angers for confocal microscopy images as well as the SCCAN ("Service Commun de Cytométrie et d'Analyse Nucléotidique") of Angers for the use of PCR facilities.

\section{REFERENCES}

1. Gimble JM, Katz AJ, Bunnell BA. Adipose-derived stem cells for regenerative medicine. Circ Res 2007;100:1249-1260.

2. Meliga E, Strem BM, Duckers HJ, Serruys PW. Adipose-derived cells. Cell Transplant 2007;16:963-970.

3. Muscari C, Bonafè F, Fiumana E, Oranges CM, Pinto V, Caldarera CM, Guarnieri C, Morselli PG. Comparison between stem cells harvested from wet and dry lipoaspirates. Connect Tissue Res 2013;54:34-40.

4. Choi YS, Dusting GJ, Stubbs S, Arunothayaraj S, Han XL, Collas $\mathrm{P}$, Morrison WA, Dilley RJ. Differentiation of human adiposederived stem cells into beating cardiomyocytes. J Cell Mol Med 2010;14:878-889.

5. Planat-Bénard V, Menard C, André M, Puceat M, Perez A, GarciaVerdugo JM, Pénicaud L, Casteilla L. Spontaneous cardiomyocyte differentiation from adipose tissue stroma cells. Circ Res 2004;94: 223-229.

6. Song YH, Gehmert S, Sadat S, Pinkernell K, Bai X, Matthias N, Alt E. VEGF is critical for spontaneous differentiation of stem cells into cardiomyocytes. Biochem Biophys Res Commun 2007;354: 999-1003.

7. Gwak SJ, Bhang SH, Yang HS, Kim SS, Lee DH, Lee SH, Kim BS. In vitro cardiomyogenic differentiation of adipose-derived stromal cells using transforming growth factor-beta-1. Cell Biochem Funct 2009;27:148-154.

8. van Dijk A, Niessen HW, Zandieh Doulabi B, Visser FC, van Milligen FJ. Differentiation of human adipose-derived stem cells towards cardiomyocytes is facilitated by laminin. Cell Tissue Res 2008;334:457-467.

9. Metzele R, Alt C, Bai X, Yan Y, Zhang Z, Pan Z, Coleman M, Vykoukal J, Song YH, Alt E. Human adipose tissue-derived stem cells exhibit proliferation potential and spontaneous rhythmic contraction after fusion with neonatal rat cardiomyocytes. FASEB J 2011;25:830-839.

10. Pasini A, Bonafè F, Govoni M, Guarnieri C, Morselli PG, Sharma HS, Caldarera CM, Muscari C, Giordano E. Epigenetic signature of early cardiac regulatory genes in native human adipose-derived stem cells. Cell Biochem Biophys 2013;67:255-262. 
11. Léobon B, Roncalli J, Joffre $C$, Mazo $M$, Boisson $M$, Barreau $C$ Calise D, Arnaud E, André M, Pucéat M, Pénicaud L, Prosper F, Planat-Bénard V, Casteilla L. Adipose-derived cardiomyogenic cells: in vitro expansion and functional improvement in a mouse model of myocardial infarction. Cardiovasc Res 2009;83:757-767.

12. Schenke-Layland K, Strem BM, Jordan MC, Deemedio MT, Hedrick MH, Roos KP, Fraser JK, Maclellan WR. Adipose tissuederived cells improve cardiac function following myocardial infarction. J Surg Res 2009;153:217-223.

13. Bayes-Genis $A$, Soler-Botija $C$, Farré J, Sepúlveda $P$, Raya $A$ Roura S, Prat-Vidal C, Gálvez-Montón C, Montero JA, Büscher D, Izpisúa Belmonte JC. Human progenitor cells derived from cardiac adipose tissue ameliorate myocardial infarction in rodents. J Mol Cell Cardiol 2010;49:771-780.

14. Bagno LL, Werneck-de-Castro JP, Oliveira PF, Cunha-Abreu MS, Rocha NN, Kasai-Brunswick TH, Lago VM, Goldenberg RC, Campos-de-Carvalho AC. Adipose-derived stromal cell therapy improves cardiac function after coronary occlusion in rats. Cell Transplant 2012;21:1985-1996.

15. Wang L, Deng J, Tian W, Xiang B, Yang T, Li G, Wang J, Gruwel M, Kashour T, Rendell J, Glogowski M, Tomanek B, Freed D, Deslauriers R, Arora RC, Tian G. Adipose-derived stem cells are an effective cell candidate for treatment of heart failure: An MR imaging study of rat hearts. Am J Physiol Heart Circ Physiol 2009; 297:H1020-H1031.

16. Pagliari S, Vilela-Silva AC, Forte G, Pagliari F, Mandoli C, Vozzi G, Pietronave S, Prat M, Licoccia S, Ahluwalia A, Traversa E, Minieri M, Di Nardo P. Cooperation of biological and mechanical signals in cardiac progenitor cell differentiation. Adv Mater 2011;23: 514-518.

17. Govoni M, Muscari C, Guarnieri C, Giordano E. Mechanostimulation protocols for cardiac tissue engineering. Biomed Res Int 2013;2013:918640.

18. Anitua E, Sánchez M, Orive G, Andia I. Delivering growth factors for therapeutics. Trends Pharmacol Sci 2008;29:37-41.

19. Ellison GM, Torella D, Dellegrottaglie S, Perez-Martinez C, Perez de Prado A, Vicinanza C, Purushothaman S, Galuppo V, laconetti C, Waring CD, Smith A, Torella M, Cuellas Ramon C, GonzaloOrden JM, Agosti V, Indolfi C, Galiñanes M, Fernandez-Vazquez F, Nadal-Ginard B. Endogenous cardiac stem cell activation by insulin-like growth factor-1/hepatocyte growth factor intracoronary injection fosters survival and regeneration of the infarcted pig heart. J Am Coll Cardiol 2011;58:977-986.

20. Behfar A, Terzic A. Derivation of a cardiopoietic population from human mesenchymal stem cells yields cardiac progeny. Nat Clin Pract Cardiovasc Med 2006;3Suppl1:S78-S82.

21. Behfar A, Faustino RS, Arrell DK, Dzeja PP, Perez-Terzic C, Terzic A. Guided stem cell cardiopoiesis: discovery and translation. J Mol Cell Cardiol 2008;45:523-529.

22. Hahn JY, Cho HJ, Kang HJ, Kim TS, Kim MH, Chung JH, Bae JW, Oh BH, Park YB, Kim HS. Pre-treatment of mesenchymal stem cells with a combination of growth factors enhances gap junction formation, cytoprotective effect on cardiomyocytes, and therapeutic efficacy for myocardial infarction. J Am Coll Cardiol 2008;51: 933-943.

23. Behfar A, Yamada S, Crespo-Diaz R, Nesbitt JJ, Rowe LA, PerezTerzic C, Gaussin V, Homsy C, Bartunek J, Terzic A. Guided cardiopoiesis enhances therapeutic benefit of bone marrow human mesenchymal stem cells in chronic myocardial infarction. J Am Coll Cardiol 2010:56:721-734.

24. Pankov R, Yamada KM. Fibronectin at a glance. J Cell Sci 2002; 115:3861-3863.

25. van Dijk A, Niessen HW, Ursem W, Twisk JW, Visser FC, van Milligen FJ. Accumulation of fibronectin in the heart after myocardial infarction: A putative stimulator of adhesion and proliferation of adipose-derived stem cells. Cell Tissue Res 2008;332:289-298.

26. Martino MM, Mochizuki M, Rothenfluh DA, Rempel SA, Hubbell JA, Barker TH. Controlling integrin specificity and stem cell differentiation in $2 \mathrm{D}$ and $3 \mathrm{D}$ environments through regulation of fibronectin domain stability. Biomaterials 2009;30:1089-1097.

27. Malan D, Reppel M, Dobrowolski R, Roell W, Smyth N, Hescheler $\mathrm{J}$, Paulsson M, Bloch W, Fleischmann BK. Lack of laminin gamma1 in embryonic stem cell-derived cardiomyocytes causes inhomogeneous electrical spreading despite intact differentiation and function. Stem Cells 2009;27:88-99.

28. Kuppuswamy D. Importance of integrin signaling in myocyte growth and survival. Circ Res 2002;90:1240-1242.

29. Villarreal FJ, Dillmann WH. Cardiac hypertrophy-induced changes in mRNA levels for TGF-beta 1, fibronectin, and collagen. Am J Physiol 1992;262:H1861-H1866.

30. Frøen JF, Larsen TH. Fibronectin penetration into heart myocytes subjected to experimental ischemia by coronary artery ligation. Acta Anat (Basel) 1995;152:119-126.

31. Willems IE, Arends JW, Daemen MJ. Tenascin and fibronectin expression in healing human myocardial scars. J Pathol 1996;179: 321-325.

32. Ulrich MM, Janssen AM, Daemen MJ, Rappaport $L$, Samuel JL, Contard F, Smits JF, Cleutjens JP. Increased expression of fibronectin isoforms after myocardial infarction in rats. $\mathrm{J}$ Mol Cell Cardiol 1997;29:2533-2543.

33. Morishita N, Kusachi S, Yamasaki S, Kondo J, Tsuji T. Sequential changes in laminin and type IV collagen in the infarct zoneimmunohistochemical study in rat myocardial infarction. Jpn Circ J 1996;60:108-114.

34. Tatard VM, Venier-Julienne MC, Saulnier P, Prechter E, Benoit JP, Menei $P$, Montero-Menei CN. Pharmacologically active microcarriers: A tool for cell therapy. Biomaterials 2005;26:3727-3737.

35. Delcroix GJ, Garbayo E, Sindji L, Thomas O, Vanpouille-Box C, Schiller PC, Montero-Menei CN. The therapeutic potential of human multipotent mesenchymal stromal cells combined with pharmacologically active microcarriers transplanted in hemiparkinsonian rats. Biomaterials 2011;32:1560-1573.

36. Garbayo E, Raval AP, Curtis KM, Della-Morte D, Gomez LA, D'Ippolito G, Reiner T, Perez-Stable C, Howard GA, Perez-Pinzon MA, Montero-Menei CN, Schiller PC. Neuroprotective properties of marrow-isolated adult multilineage-inducible cells in rat hippocampus following global cerebral ischemia are enhanced when complexed to biomimetic microcarriers. J Neurochem 2011;119: 972-988.

37. Giteau A, Venier-Julienne MC, Aubert-Pouëssel A, Benoit JP. How to achieve sustained and complete protein release from PLGAbased microparticles? Int J Pharm 2008;350:14-26.

38. Bouffi C, Thomas O, Bony C, Giteau A, Venier-Julienne MC, Jorgensen C, Montero-Menei C, Noël D. The role of pharmacologically active microcarriers releasing TGF-beta3 in cartilage formation in vivo by mesenchymal stem cells. Biomaterials 2010;31: 6485-6493.

39. Tatard VM, Venier-Julienne MC, Benoit JP, Menei P, MonteroMenei $\mathrm{CN}$. In vivo evaluation of pharmacologically active microcarriers releasing nerve growth factor and conveying PC12 cells. Cell Transplant 2004;13:573-583.

40. Tatard VM, Sindji L, Branton JG, Aubert-Pouëssel A, Colleau J, Benoit JP, Montero-Menei CN. Pharmacologically active microcarriers releasing glial cell line-derived neurotrophic factor: Survival and differentiation of embryonic dopaminergic neurons after grafting in hemiparkinsonian rats. Biomaterials 2007;28: 1978-1988.

41. Penna C, Perrelli MG, Karam JP, Angotti C, Muscari C, MonteroMenei CN, Pagliaro P. Pharmacologically active microcarriers influence VEGF-A effects on mesenchymal stem cell survival. J Cell Mol Med 2013;17:192-204.

42. Musilli C, Karam JP, Paccosi S, Muscari C, Mugelli A, MonteroMenei CN, Parenti A. Pharmacologically active microcarriers for endothelial progenitor cell support and survival. Eur J Pharm Biopharm 2012;81:609-616.

43. Morille M, Van-Thanh T, Garric X, Cayon J, Coudane J, Noël D, Venier-Julienne MC, Montero-Menei CN. New PLGA-P188-PLGA matrix enhances TGF- $\beta 3$ release from pharmacologically active microcarriers and promotes chondrogenesis of mesenchymal stem cells. J Controlled Release 2013;170:99-110.

44. Vandesompele J, De Preter K, Pattyn F, Poppe B, Van Roy N, De Paepe A,Speleman F. Accurate normalization of real-time quantitative RT-PCR data by geometric averaging of multiple internal control genes. Genome Biol 2002;3:RESEARCH0034.

45. Naito AT, Tominaga A, Oyamada $M$, Oyamada $Y$, Shiraishi I, Monzen K, Komuro I, Takamatsu T. Early stage-specific inhibitions 
of cardiomyocyte differentiation and expression of Csx/Nkx-2.5 and GATA-4 by phosphatidylinositol 3-kinase inhibitor LY294002. Exp Cell Res 2003;291:56-69.

46. Yamada Y, Sakurada K, Takeda Y, Gojo S, Umezawa A. Single-cellderived mesenchymal stem cells overexpressing Csx/Nkx2.5 and GATA4 undergo the stochastic cardiomyogenic fate and behave like transient amplifying cells. Exp Cell Res 2007;313:698706.

47. Armiñán $A$, Gandía $C$, Bartual $M$, García-Verdugo JM, Lledó $E$, Mirabet V, Llop M, Barea J, Montero JA, Sepúlveda P. Cardiac differentiation is driven by NKX2.5 and GATA4 nuclear translocation in tissue-specific mesenchymal stem cells. Stem Cells Dev 2009; 18:907-918.

48. Li TS, Komota T, Ohshima M, Qin SL, Kubo M, Ueda K, Hamano K. TGF-beta induces the differentiation of bone marrow stem cells into immature cardiomyocytes. Biochem Biophys Res Commun 2008;366:1074-1080.

49. Kawaguchi N. Adult cardiac-derived stem cells: Differentiation and survival regulators. Vitam Horm 2011;87:111-125.

50. Moriscot AS, Sayen MR, Hartong R, Wu P, Dillmann WH. Transcription of the rat sarcoplasmic reticulum $\mathrm{Ca} 2+$ adenosine triphosphatase gene is increased by 3,5,3'-triiodothyronine receptor isoform-specific interactions with the myocyte-specific enhancer factor-2a. Endocrinology 1997;138:26-32.

51. Leszczynski J K, Esser AK. The MEF2 site is necessary for induction of the myosin light chain 2 slow promoter in overloaded regenerating plantaris muscle. Life Sci 2003;73:3265-3276.

52. Zhang Z, Li H, Ma Z, Feng J, Gao P, Dong H, Zhang Z. Efficient cardiomyogenic differentiation of bone marrow mesenchymal stromal cells by combination of Wnt11 and bone morphogenetic protein 2. Exp Biol Med (Maywood) 2012;237:768-776.

53. Kirby ML. Molecular embryogenesis of the heart. Pediatr Dev Pathol 2002;5:516-43.

54. Dunwoodie SL. Combinatorial signaling in the heart orchestrates cardiac induction, lineage specification and chamber formation. Semin Cell Dev Biol 2007;18:54-66.

55. Chien KR, Domian IJ, Parker KK. Cardiogenesis and the complex biology of regenerative cardiovascular medicine. Science 2008; 322:1494-1497.

56. Taubenschmid J, Weitzer G. Mechanisms of cardiogenesis in cardiovascular progenitor cells. Int Rev Cell Mol Biol 2012;293:195-267.

57. Durocher D, Charron F, Warren R, Schwartz RJ, Nemer M. The cardiac transcription factors $\mathrm{Nkx2}-5$ and GATA-4 are mutual cofactors. EMBO J 1997;16:5687-5696.

58. Mohanty S, Bose S, Jain KG, Bhargava B, Airan B. TGFbeta1 contributes to cardiomyogenic-like differentiation of human bone marrow mesenchymal stem cells. Int J Cardiol 2013;163: 93-99.

59. Yang HS, Bhang $\mathrm{SH}$, Kim IK, Lee TJ, Kang JM, Lee $\mathrm{DH}$, Lee $\mathrm{SH}$ Hwang KC, Kim BS. In situ cardiomyogenic differentiation of implanted bone marrow mononuclear cells by local delivery of transforming growth factor- $\beta 1$. Cell Transplant 2012;21:299-312.

60. Hu DL, Chen FK, Liu YQ, Sheng YH, Yang R, Kong XQ, Cao KJ, Gu HT, Qian LM. GATA-4 promotes the differentiation of P19 cells into cardiac myocytes. Int J Mol Med 2010;26:365-372.

61. Pashmforoush $\mathrm{M}$, Lu JT, Chen $\mathrm{H}$, Amand TS, Kondo $\mathrm{R}$, Pradervand S, Evans SM, Clark B, Feramisco JR, Giles W, Ho SY, Benson DW, Silberbach M, Shou W, Chien KR. Nkx2-5 pathways and congenital heart disease; loss of ventricular myocyte lineage specification leads to progressive cardiomyopathy and complete heart block. Cell 2004;117:373-386.

62. Battista S, Guarnieri D, Borselli C, Zeppetelli S, Borzacchiello A, Mayol L, Gerbasio D, Keene DR, Ambrosio L, Netti PA. The effect of matrix composition of $3 \mathrm{D}$ constructs on embryonic stem cell differentiation. Biomaterials 2005;26:6194-6207.

63. Smith RR, Barile L, Cho HC, Leppo MK, Hare JM, Messina E, Giacomello A, Abraham MR, Marbán E. Regenerative potential of cardiosphere-derived cells expanded from percutaneous endomyocardial biopsy specimens. Circulation 2007;115:896-908.

64. Davis DR, Zhang $Y$, Smith RR, Cheng K, Terrovitis J, Malliaras K Li TS, White A, Makkar R, Marbán E. Validation of the cardiosphere method to culture cardiac progenitor cells from myocardial tissue. PLoS One 2009;4:e7195.

65. Saffitz JE, Yamada KA. Do alterations in intercellular coupling play a role in cardiac contractile dysfunction? Circulation 1998;97:630632.

66. Wang $\mathrm{Y}$, Cheng $\mathrm{Y}$. The tail of $\mathrm{C} x 43$ : Its crucial protective role in acute myocardial infarction. Cardiovasc Res 2009;84:337-338.

67. Danik SB, Liu F, Zhang J, Suk HJ, Morley GE, Fishman Gl, Gutstein DE. Modulation of cardiac gap junction expression and arrhythmic susceptibility. Circ Res 2004;95:1035-1041.

68. Maass K, Chase SE, Lin X, Delmar M. Cx43 CT domain influences infarct size and susceptibility to ventricular tachyarrhythmias in acute myocardial infarction. Cardiovasc Res 2009;84:361-367.

69. Neuhaus J, Heinrich M, Schwalenberg T, Stolzenburg JU. TGFbeta 1 inhibits $\mathrm{Cx} 43$ expression and formation of functional syncytia in cultured smooth muscle cells from human detrusor. Eur Urol 2009;55:491-497.

70. Hawat G, Hélie P, Baroudi G. Single intravenous low-dose injections of connexin 43 mimetic peptides protect ischemic heart in vivo against myocardial infarction. J Mol Cell Cardiol 2012;53:559566. 